\title{
Archery by the Apaches - implications of using the bow and arrow in hunter-gatherer communities
}

\author{
Žiga Šmit 1,2 \\ 1 Faculty of Mathematics and Physics, University of Ljubljana, SI \\ 2 Jožef Stefan Institute, Ljubljana, SI \\ ziga.smit@fmf.uni-lj.si
}

\begin{abstract}
This review focuses on the technical and social details of production, training, and use of archery equipment by a Native American tribe, the Apaches. The study aims to understand the use of the bow in the Mesolithic and Early and Middle Neolithic societies of the Old World. The paper further describes arrow ballistics. An arrow and bow with similar dimensions and materials to those used by the Apaches was reconstructed and used in ballistic experiments. Shooting and the subsequent model calculation showed that the effective range of arrows made of reed and projected by a bow of medium strength (16-18kg) was not more than approx. 20m. Due to the initial flat part of the ballistic trajectory, such arrows were quite efficient in close-range contests. Within the model calculation, a regression procedure was introduced to determine the arrow air-drag parameters from an ensemble of shots.
\end{abstract}

IZVLEČEK - Članek podaja pregled o tehničnih in socioloških podrobnostih pri izdelavi, treningu in rabi lokostrelske opreme pri ameriškem domorodnem plemenu Apačev. Študija je namenjena razumevanju rabe loka in puščic $v$ mezolitskih ter zgodnje in srednje neolitskih kulturah Starega sveta. Drugi del študije se ukvarja z balistiko puščice. Predmet balističnih preizkusov sta bila puščica in lok podobnih dimenzij in materialov, kot so jih uporabljali Apači. Streljanje in modelsko računanje sta pokazala, da uporabni doseg puščice, izdelane iz trstike in izstreljene z loka srednje moči (16-18 kg), ni večji od približno 20 metrov. Ker je balistična krivulja take puščice v prvem delu leta zelo položna, so bile puščice izredno učinkovite na kratko razdaljo. V modelskem računu smo uvedli nov postopek za določanje parametrov zračnega upora iz skupine strelov.

KEY WORDS - Apache; bow and arrow; reed arrow

\section{Introduction}

The invention of the bow and arrow provided the early hunter with a remarkable hunting tool. However, in complex human relations, it also turned into an efficient weapon to be used against others. In the prehistoric old World, various testimonies to human violence exist, most of them manifested in changes in human skeletons, although some explicitly point to injury caused by an arrow. The earliest evidence of armed conflict from the Late Paleolithic (12000-10000 BC) is from Jebel Sahaba in Sudan, where half of 107 burials suggest violent death (Christensen 2004.134). Projectile injuries in the Middle and Upper Paleolithic are rare, but in the Mesolithic they amount to 17 out of total of 77 registered exam- ples, or 22\% (Estabrook 2014.65). A review by the same author (Estabrook 2014.53-58) lists the following Mesolithic sites with projectile bone injuries: Bøgebakken in Denmark (two perimortem projectiles), Vlasac (one perimortem bone projectile) and Schela Cladovei in the Danube region (6 perimortem flint or bone projectiles), and Vasilyevka in Ukraine (8 perimortem projectiles). Regarding the Vlasac example, the author also admits the possibility that the wound was inflicted by a dart (Roksandic 2006b. 342). Further examples of Mesolithic death caused by projectile injuries (Christensen 2004.134-135) include Téviec in France (two arrowheads in the spinal column) and Henricksholm/ Bøgebakken in 
Denmark (bone point in the throat). From the Mesolithic and Neolithic, we have further evidence in graphic depictions showing armed contests between archers. In Les Dogue, Ares del Maestra, eleven archers are attacked by seventeen running archers, and in Cueva del Roure, Morella, four archers are in the pincers of three others (Christensen 2004.135). In a mass grave at Talheim in Heilbronn, dated to the Early Neolithic, two individuals among 34 burials show injuries caused by arrow points. From the Middle and Late Neolithic, finds of human bones with embedded flint or bone tipped arrows are numerous: Castellet, Villevénard and Roaix in France, Porsmosen in Denmark, the Stapleton enclosure near Dorset and Stonehenge in the UK (Christensen 2004.136-137), Aktopraktic in Anatolia (Erdal 2012. 80 ). Two projectile injuries out of a total of ten traumatic injuries are also documented for Paleoamericans in North America (Chatters 2014.75).

The intensity of conflict may be estimated from the percentage of individuals showing signs of violent death in a certain grave assemblage. In Schela Cladovei, in the area of the Iron Gates, $15 \%$ of individuals died violently from shots of arrows tipped with bone points (Bonsall 2008.263). On the other hand, Mirjana Roksandić (2006a) estimates that conflicts were occasional, as among the 418 individuals she studied, only a few showed the consequences of violence. An opposite view is given by Jonas Christensen (2004.130): armed conflict in primitive societies caused 10-40\% loss of population. For Linear Pottery culture, the skeletal material is well documented and shows that $20 \%$ of the population died violently (Christensen 2004.152).

As material remnants provide only limited sources of complex human relations, behaviour patterns are also studied by ethnographic research on contemporary, but archaic, societies which are still attached to their traditional way of life and have survived in a few remote parts of the world. The cultural groups most studied today or in recent decades are huntergatherer communities in Alaska or Australasia ( $\mathrm{Kra}$ mer 1979.3; LeBlanc 2014). However, with modern communication technologies, their life-style is rapidly disappearing, and many interesting data can be found only in the literature published since the second half of the 19th century. The present work aims to study the use of the bow by the Apaches, an indigenous tribe in the south-west of North America, about whom significant data exist in their memorial literature from the end of the $19^{\text {th }}$ century and in ethnographic studies published between 1930 and 1960. In a review, we would like to give a comprehensive view of the technology of making archery equipment and the use of bows in hunting and combat. In the second part, we try to reproduce some specific item of archery equipment, notably reed arrows, and test their ballistic properties.

The Apaches, the Athabaskan-speaking native population, settled in the area of present-day Arizona, New Mexico and the northern borders of Chihuahua and Sonora between the early $15^{\text {th }}$ and $16^{\text {th }}$ centuries. Among this large group, we limit our study to the Chiricahuas and Western Apaches. The main memorial literature on the Chiricahua is the account of Geronimo as recorded by Stephen M. Barrett in 1906 (1996), and the autobiography of Jason Betsinez (1959). Many observations can also be found in the works of Eve Ball (1988; 2003). For the Western Apaches, ethnographic material and memories of war parties from the second half of the $19^{\text {th }}$ century were recorded by Grenville Godwin and are available in Keith H. Basso's book (Basso 1971).

By the first half of the 19th century, the Apaches were living quite an independent way of life, during the period that started with Mexican independence in 1810-1821 and ended with the MexicanAmerican war in 1846. This period is characterised by an absence of organised Mexican military control, while the influence of white Americans was almost negligible. Relations with Mexicans were complex, involving peaceful co-existence and fierce military conflicts (Utley 2012.16-28). The Chiricahua economy was based on four main activities: hunting, gathering, modest farming, and casual looting of their Mexican neighbours. During looting expeditions or raids against the Mexicans, they usually used cold weapons, as described in the memories of Geronimo. The Western Apache economy was more advanced, being primarily agricultural; they also built dams and dug irrigation ditches (Basso 1971.79). However, it is interesting that they quit the irrigated cornfields as soon as the corn ears developed, and temporarily left to collect acorns (Basso 1971. 95-96). The Western Apaches generally made the transition to reservation life much more easily than the Chiricahuas. In the earlier period, the Chiricahuas also organised two kinds of military expedition: smaller parties of up to fifteen warriors generally aimed at looting, while a large number of warriors led by respected chieftains and a shaman (Basso 1971.16-18) normally avenged the deaths of casualties. 
During this period, the bow was used as an effective long-range weapon, supported by the fact that contemporary guns were muzzle-loaders superior to their predecessors of previous centuries in having a more efficient firing system of percussion caps only. Mexican military doctrine had remained essentially unchanged since the Napoleonic wars and was based on the organised concentrated fire of multiple weapons, rather than on precise individual musketry. In such circumstances, the bow could compete with the gun in range and precision, and bettered it in the rate of fire.

\section{Use of the bow}

\section{Hunting}

Hunting was the main activity of men and boys as soon as they passed the age of eight or ten (Barrett 1996.65). The bow and arrow was not the only hunting weapon; larger animals were also hunted with the spear and smaller ones with a short stick or a hunting club. Horses were also used in hunting, notably for catching up with smaller animals such as turkeys and rabbits. The bow and arrow (but also spear) from horseback were used to hunt buffalo (Barrett 1996.64), though for Apaches, the buffalo was probably an occasional pray. Geronimo carefully describes efforts during deer hunting, which was based on concealed approach to a grazing herd. A skillful hunter could get several animals before the rest of the herd noticed him and ran away. Although not described explicitly, this type of hunting was possible only with bow and arrow. A good shot could kill a deer instantly at a distance of a hundred yards (90m).

Another animal that Geronimo explicitly says was hunted with the bow is mountain lion, although he also says he killed one with a spear (Barrett 1996. 68). The bow and arrow can also be used for some unusual practices, such as shooting down parts of a beehive of wild bees (Ball 2003.122).

The bow was used for hunting during the Turkey Creek settlement period (Davies 1929.102-120) as late as 1884 , possibly due to the scarcity of ammunition (Ball 2003.159). Jason Betsinez remembers that the men used the bow to kill domestic animals allotted to them for food (Betsinez 1959.6). He was also impressed by the penetrative ability of the arrow, as he writes, "Many men can drive an arrow clear through a large animal." At a distance of $14 \mathrm{~m}$, an arrow could be sent through a deer (Opler 1996.388).

\section{Combat}

The Chiricahuas used the bow as the main ballistic weapon until about 1860 . It was at the battle of Apache Pass in 1862 that they first used a considerable number of firearms - although most of them still carried bows and arrows (Ball 1988.20) - but they probably lacked sufficient ammunition (Sweeney 1991.437). During the 1870s, bows were used in small-scale conflicts on the Tularosa Reservation (Thrapp 1974.156). In an ambush set for Mexican soldiers in 1875 near Fronteras, the Mexican commander was reportedly killed by an arrow (Sweeney 2010.37). Bows were often used in internal conflicts and scuffles, which regularly followed excess consumption of alcohol (Sweeney 2010.26). Geronimo describes treating wounds after such fighting (Barrett 1996.96). Betsinez remarks that bows were seldom used after 1882 (Betsinez 1959.85). In spite of this, Bourke noticed in 1883 during the Mexican campaign of General Crook that the Apache still carried bows and arrows as a side arm, as well as the latest repeating rifles and revolvers (Bourke 1958. 102). The Western Apaches conducted raiding parties in Mexico armed with bows until the 1850s or 1860s (Basso 1971.84, 195).

Most Apache raiding parties started on foot, and each warrior carried equipment and rations for three days (Barrett 1996.84). From a description of fighting scenes in Geronimo, we learn that personal arms consisted of a spear, bow, arrows, and a knife (Barrett 1996.93), and eventually also a war club (Opler 1996.340). The number of arrows carried in important encounters was between thirty and forty (Opler 1996.388). In three places in his memoirs, Geronimo says that he ran short of arrows during a fight. The first two were in fights with Mexicans. In a supposed revenge battle (probably the battle at Pozo Hediondo in 1851), Geronimo used all his arrows in about two hours of fighting (Barrett 1996. 62). In some other attempt to raid an unnamed village, an Apache party was ambushed and pursued (Barrett 1996.85). The soldiers subsequently chased the Apaches, who were fleeing and hiding. From his hiding place, Geronimo used his bow to defend himself against soldiers who had spotted him. According to his account, he had enough time to take deliberate aim from a concealed place until he had spent all his arrows. These circumstances do not allow us to determine the range at which Geronimo used his bow, but the distances were supposedly from some tens of metres up to a hundred metres. When he left the hiding place, mounted Mexicans threatened to cut him off. In this case, the bow would have been 
used at very close range. The third description refers to a conflict with United States soldiers in 1863, 1864 (Barrett 1996.120). The Apaches were only modestly armed, so Geronimo soon spent all his arrows. In a fight ten days later, he had spent all his arrows before ten o'clock in the morning, although the fighting lasted the whole day.

The bow's short range made it ineffective against firearms. On a raiding party near Arispe around 1867 , the Apaches were pursued by Mexican horsemen (Barrett 1996.99). When they opened fire, they were too far away for the Apaches to respond with their bows. However, bows had sufficient range to shoot after the fleeing enemy (Barrett 1996.93). The bow was effective in short-range combat. This was seen when Mexican troops attacked Geronimo's settlement (Barrett 1996.89). In the thick of the fighting, Geronimo was able to shoot an officer and escape. The rate of fire of the bow was an advantage even in contests with modern repeating guns. As claimed by an unnamed warrior, it was possible to shoot three arrows before the opponent could load the magazine of the gun (Opler 1996.388). Longrange shooting is recorded for the Mescalero Apaches. In 1868, they besieged Mexican soldiers who had taken their horses into an enclosure. The Apaches shot their arrows high in the air so they fell into the enclosure and killed all the animals (Sonnichsen 1958.144).

\section{Production of archery equipment and training}

Archery equipment was manufactured by experienced old men who passed on their knowledge to the young (Basso 1971.226). Young boys had to observe men making bows (Opler, 1996.28). If the older man was a relative, he made the bow for free, but should then receive a portion of prey or booty without asking (Basso 1971.226). If the bow maker and owner were not related, the payment would be a shirt or buckskin (Opler 1996.226). Men were supposed to make arrows themselves. Making a full quiver of arrows took a month (Opler 1996.388).

Apaches trained to fire the bow from early childhood (Oper 1996.50-51). In a Massai legend (Betsinez 1959.143; Ball 1988.248-261), we learn that a child had to shoot through metal ring approx. $90 \mathrm{~m}$ away (Ball 1988.248). In 1869, Mexican troops caught a man in the Guadalupe Canyon who had taught a boy how to make arrows (Sweeney 1991. 267). Children practiced bow shooting until the 1880 s, when the bow was no longer used as a wea- pon (Ball 2003.113). Young Chiricahuas trained by shooting fish in streams, although animals like frogs and snakes were never eaten (Barrett 1996.68). Mastering the bow was also developed through numerous archery games; the contests involved shooting into the distance or touching the arrow shot by the first contestant. If the arrows touched, the second archer could keep both arrows. If he missed, his arrow served as a new target. A roll of twisted grass was thrown into the air and had to be hit before it touched ground (Opler 1996.50-52).

Even in adulthood, knowledge of the bow was maintained by frequent competitions. These events also involved fast shooting. The aim was to shoot three arrows before the first touched ground (Opler 1996. 391). A ball made of cedar bark was used for target shooting (Basso 1971.226).

The string was held by the middle three fingers of the right hand, with the first finger above the arrow nock. The bow was held with the left hand, and the arrow rested on left side of the bow on the archer's thumb (Basso 1971.225). The three fingers could also be used so the string was held between the thumb and first finger, with the second finger assisting (Opler 1996.388). For close shots, the bow was held vertically, but for long shots the bow was held crossways (Basso 1971.226). Aiming was taken along the arrow. A wrist guard made of rawhide (Opler 1996.391) or leather (Basso 1971.224) was often worn on the left wrist to protect the wrist when it hit the string (Basso 1971.225).

\section{Making the bow}

Apache bows were made from mulberry wood. The Chiricahuas cut second-growth trees found at foot of the hills (Betsinez 1959.5). After being cut, the wood was dried for a long time and then worked to the proper size, which was a man's wrist in the middle and tapering at the ends (Betsinez 1959.6). The Western Apaches also used mulberry wood, but fashioned the bow when the wood was still green, and then they hung it to dry for about five to seven days. The shape of the bow was a simple arc, with a straight middle section and flexible limbs. The Western Apaches also used bows in the shape of double arc, but learned that single arc bows are better. The double arch could be formed only when the wood was still fresh (Basso 1971.223-224). Oak, locust and New Mexico maple also furnished acceptable wood (Opler 1996.386). 

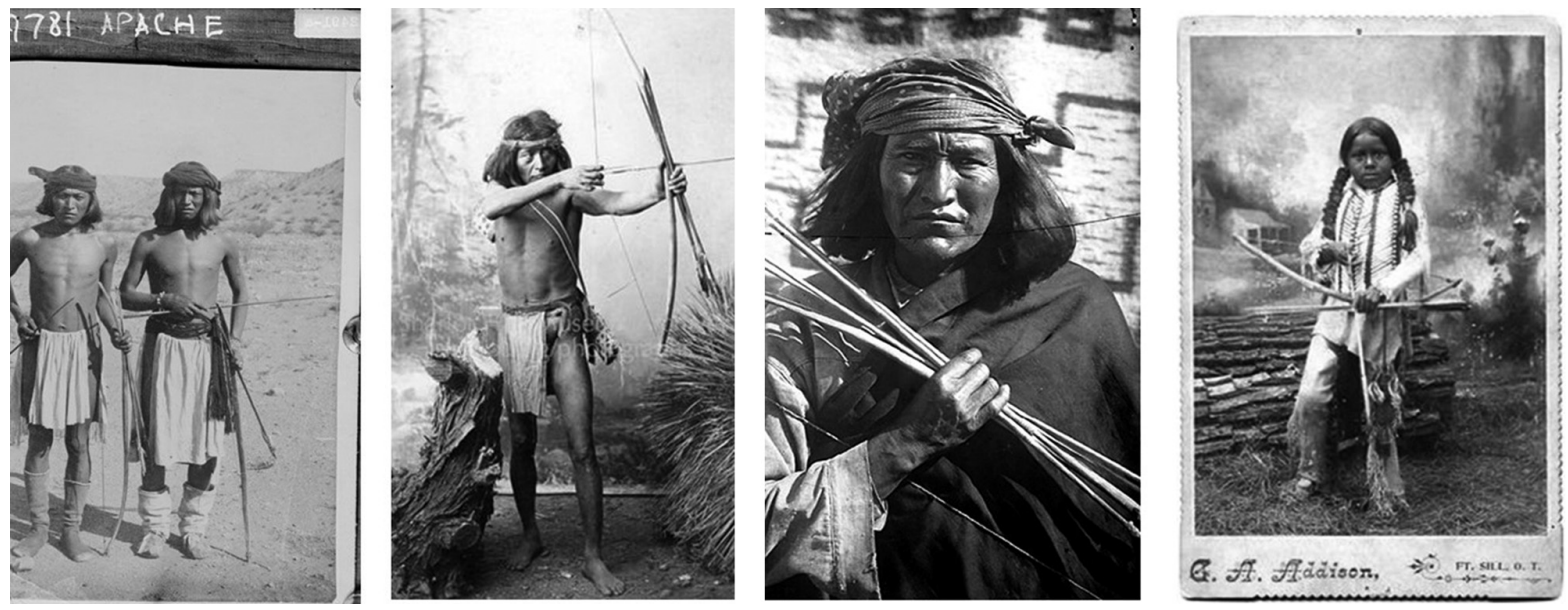

Fig. 1. Photographs of Apache warriors with bows and arrows: two youths at San Carlos Agency in 1888 (Utley 1977), a warrior around 1860 (artificial scenery in the studio), Chatto, chief and later army scout, with reed arrows and boy with a child's bow (Fort Sill after 1894).

The shape of single-arc bows can be seen from a few photographs showing warriors with full equipment (Fig. 1). Comparing the bow size with the dimensions of the human body, the length of the bow with stretched string was between 1-1.2m. Opler states "three to four feet" or the "length of two arrows", adding "the short or hardwood shafted arrows" in the note (Opler 1996.386). The bow could also be smaller for hunting small animals and for training boys (Opler 1996.388). A size of $1.3-1.4 \mathrm{~m}$ can be deduced from the photograph taken in the studio (Fig. 1); however, the bow here may also be an improvised item. Nevertheless, we learn from these photos that Apache warriors transported and shot the bow with several arrows in the hand that held the bow, being thus ready for a rapid exchange of shots. There are also several photographs of Geronimo making bows (Fig. 2). Some reveal the bow profile, with a width of about $4 \mathrm{~cm}$ at the grip and a length of $1 \mathrm{~m}$. Supposedly, these dimensions were traditional, although one should not overlook that the bows in Geronimo's photographs were made for sale to tourists, and that Geronimo was wise enough to adjust his production to demand. It is known, for instance, that the Western Apaches made bows for tourists of lower quality wood (Basso 1971.223).

In the crafting procedure, the branch is cut, split, shaped and smoothed, and then left to season (Opler 1996.386). The wood was then greased and made slick and shiny. To bend into its final form, it was heated in hot ashes, shaped and then tied and left to dry for about ten days. To shape a double-arc bow, bending was easily achieved between two young trees growing close together (Opler 1996. 386).
The outer surface of the bow was painted in a solid color, while the inner surface was decorated with stars, crosses, serrated or parallel lines, or naturalistic figures (Opler 1996.386). The inner part of the bow is seen in a few photographs of Geronimo. In one of them, we can recognise a zigzag line and on another a series of triangles (Fig. 2).

The bowstring of the Western Apaches was made of sinew from the back of the deer or from the mus-
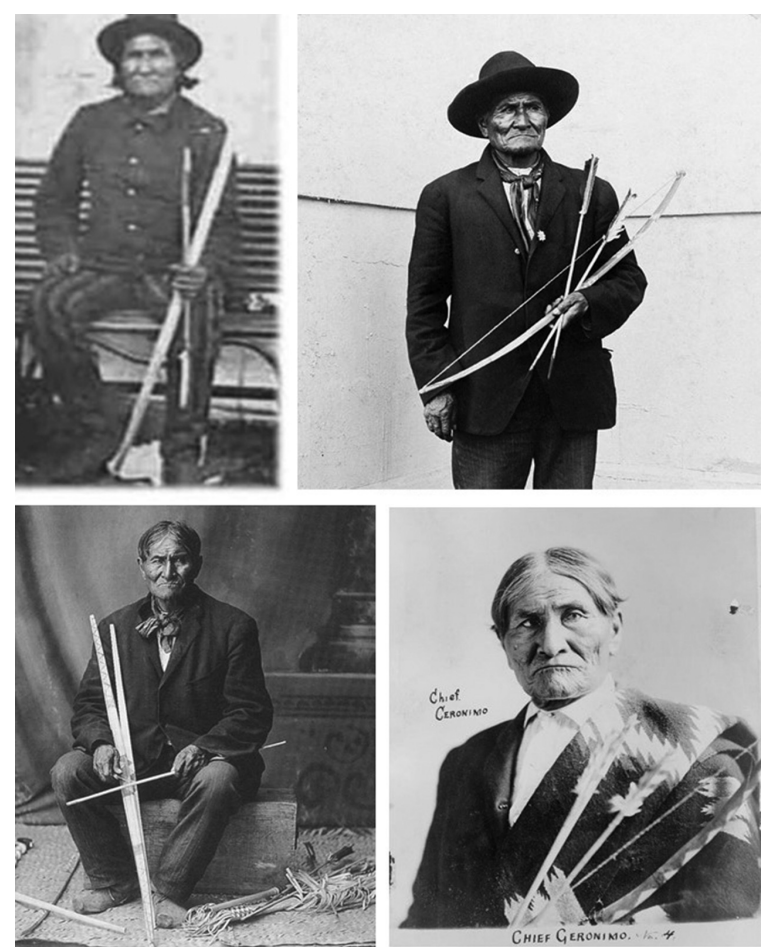

Fig. 2 Selected photographs of Geronimo posing with a self-made bow. Top row, left: in Mont Vernon, between 1888-1894; Bottom row, left: in St. Louis, 1904. 
cle of the hind legs. The sinew was soaked and split into strips that were spliced together. The long string was then doubled and twisted together. The string was gradually made tighter after it was first put on the bow (Basso 1971.224). Twisted sinew was also used for bowstrings made by the Chiricahuas (Betsinez 1959.0). The warrior usually carried an extra string in case one should snap. If necessary, a good string could also be woven from the fibres of the mescal leaf. When not in use, bows were carried unstrung (Opler 1996.387-388).

Although the Apaches never produced composite bows with a sinew layer on the outer part of the limbs, they could use sinew or horse hair to bind a bow that was weakened by use. The sinew was fixed with glue made from boiled hooves and horns or occasionally piñon pitch (Opler 1996. 387). Sometimes pitch was rubbed into the inner side of the bow to strengthen it (Basso 1971.230). For comparison, the existence of composite bows in the European Neolithic is inferred from a rock carving in a Corded Ware tomb in Gölitzsch near Merseburg (Christensen 2004.139).

\section{Arrows}

The Apaches used two types of arrow, made either from reed for close range or full hard wood for long range (Opler 1996.388). The Apache had learned about using full-wood arrows from the Navajo (Basso 1971.230). Betsinez could not remember the name of the bush that produced straight stalks (Betsinez 1959.6), but the Western Apaches used desert broom (Baccharis sarothroides) (Basso 1971.229). The Chiricahuas could also use Apache plume, mulberry, mountain mahogany or Fendlera rupicola ( $O P$ ler 1996.388). The shorter full wood arrows were heavier than the longer reed ones. The wood was cut into appropriate lengths, peeled of bark and scraped and dried for three to five days. The sticks were straightened by pressing between the teeth or against a heated rock (Opler 1996.388).

Reed arrows were actually composite. The front part with the point and the end part for the flight feathers and nock were made of hardwood, while the middle section was reed cane. The best reed was collected along the San Carlos River, but also deeper inside Mexico (Basso 1971.227). Reeds were collected green and fresh. They were straightened between the teeth and then allowed approximately two weeks to dry. Straightening could also be achieved by heating, and then rubbing the reed with a piece of heat- ed discarded pottery (Opler 1996.390). The arrow shafts were smoothed by a stone arrow-smoother (Basso 1971.229), which was made of a porous, whitish soft stone collected in Bear Canyon. A notch was made in the stone and the arrow was run through the groove when the stone was heated.

Reed arrows were typically about $75 \mathrm{~cm}$ long, while those made entirely of hard wood were about 5$10 \mathrm{~cm}$ shorter (Opler 1996.390). The size of the arrows and bow was further adapted to the needs of the particular user.

The flight feathers could be from different birds, although turkey feathers proved the most durable (Opler 1996.388). The feathers of eagles and smaller birds of prey such as the red-tailed hawk (Basso 1971.227) were also highly prized, but were hard to collect (Barrett 1996.68; Betsinez 1959.6). Tail or wing feathers were split in half and fixed to the shaft with sinew; sometimes an adhesive made of pitch was also applied. Usually, one feather was fixed first and the other two were added one by one. The parts of the flight had to be of different feathers, and had to have the same direction of rotation (Basso 1971.230; Opler 1996.389). The length of particular feathers was $12-15 \mathrm{~cm}$ (Basso 1971. 388 ). For a child's arrow or an arrow intended for hunting birds and small animals, a single long feather could have been wound spirally around the shaft for a length of about 20cm (Opler 1996.390).

The Western Apaches painted the last part of the arrow in red-black using hematite and charcoal as pigments; the dye was fixed with piñon pitch (Basso 1971.230). The painted shafts were polished with yucca leaves. The Chiricahuas decorated their arrows with black, blue or red stripes. A narrow band of green or red was traced on the upper part of the shaft that was to hold the feathers. Arrows were sometimes fluted with a sharp stone, or a spiral was made in them (Opler 1996.388-389). The fluted arrow might have resembled a crawling snake (Opler 1996.286). The style of the arrow generally indicated which tribe had made it (Basso 1971.229).

The front shaft of the reed arrow was about $10 \mathrm{~cm}$ long, approximately half of which was in the reed and half protruding outside (Opler 1996.390). The shaft was set into the cane with pitch. The shaft held the arrow point, which could be of four types: stone, steel, sharpened wooden tip and wooden shaft with a four crosspiece rig (Basso 1971.230-231). The points filed from iron or steel were used in the $19^{\text {th }}$ 
century when flint points were already a thing of the distant past (Betsinez 1959.5). Hardwood tips were additionally hardened by fire (Opler 1996. 389-390). The Western Apaches used hardwood points equipped with a crosspiece for hunting birds (Basso 1971.231). The tip of the arrow was split with two notches, the crosspiece was inserted and the tip was bound firmly together with a sinew.

Flint points are interesting, of course, as they may resemble Stone Age examples from Europe. Unfortunately, the Apaches were not highly skilled at stone knapping. They usually sought flint from around ancient ruins (Basso 1971.231) and often used readymade points (Opler 1996.389). They knew the artefacts belonged to an older people, and thought that some of the elaborate tools they found belonged to the mythical 'Thunder People' (Opler 1996.389) or that animals and birds had made them and used them to fight each other (see Barrett 1996.49; Opler 1994.23-27). There is a record of Chiricahuas splitting slate and using the most likely pieces for arrowheads (Opler 1996.389). It seems the Western Apaches were more advanced at working flint. They are documented as having held the flint with a piece of buckskin in the palm and using deer horn about $13 \mathrm{~cm}$ long to flake and shape the stone into its desired form (Basso 1971.231). An interesting record of splitting flint by heating it in fire and cooling it in water can be found in the memoirs of Herman Lehman (1993.93). However, this description has to be taken with reservations, because in the opinion of certain Comanches and Kiowas, the story is false (Robinson 2000.63).

To mount the arrowhead, the shaft was split or a notch cut; the point was inserted and the shaft was firmly tied on with moistened sinew (Opler 1996. 389, Basso 1971.231).

\section{Quivers and bow covers}

Quivers were made of various skins and usually contained thirty to forty arrows (Basso 1971.234). Mountain lion skin was the most popular (Barrett 1996.68; Basso 1971.234; Opler 1996.391), while deer, wolf, wildcat, antelope and otter were used, as well as domestic animal skins in later periods. The tail and legs were left to hang, and red flannel and brass studs could be added as additional decoration. The quiver was worn on the back, with the strap passing over the right shoulder and under the left arm, making it easy to draw an arrow with the right hand (Basso 1971.234). The Chiricahuas reversed the quiver in combat, so that the feathers came under the left armpit. Sometimes the quiver was held over the chest (Opler 1996.341).

The Western Apaches used plain quivers, while the Chiricahuas preferred quivers combined with bow cases. To make the quiver and bow cover, women usually prepared the skin, men cut out the desired pieces, while sewing was again a woman's task ( $O p$ fer 1996.380, 391).

\section{Poisoned arrows}

The use of poison is seldom mentioned with respect to Apache warfare or hunting. The use of arrows soaked in a mixture of rattlesnake blood, prickly pear pulp and charcoal from a tree struck by lighting is known for the Navajo (Hampton Sides 2007. 3 ), but these have a more ritual or symbolic meaning. Lehman also mentions that the quiver contained a few arrows poisoned with rattlesnake venom to be used in battle (Lehman 1993.94).

The Chiricahuas occasionally used poisened arrows (Opler 1996.340). The poison was prepared from deer blood and plants believed to be poisonous. The mixture was left to rot and then put on the arrow points; variations of recipes including animal parts and different plants also existed. If somebody was hit with a poisoned arrow, he was expected to turn black.

The Western Apaches seemed to have been more inclined to use poison in combat and hunting (Basso 1971.232-234). The poison was made of deer spleen. First it was dried, then mixed with the ground roots or stalk of nettles and some other plants with a burning taste. The ingredients were put in a sack of deer intestine and hung on a tree for about three to five days. The liquid was then painted on the arrow tips. The dried poison was also efficient if ground and mixed with spit. A deer pierced or merely scratched with a poisoned arrow could run about seven hundred meters before falling, but the poison spoiled only the meat near the wound.

\section{The experiment}

\section{Archaeological examples}

Remnants of reed arrows have been discovered in several caves, such as the Fort Stanton Cave. The reconstruction of reed arrows can be seen in the museums in San Carlos, Mescalero and Fort Stanton. On territory once settled by the Apaches, the author 
noted several traces of the flint industry at the northern entrance to the Ojo Caliente canyon (Winston, New Mexico) and at Turkey Creek (Fort Apache, Arizona). Several pieces were triangular in form, but it is impossible to guess if they were indeed used as arrow heads. The only fragment where the identification of an arrow head is not problematic is shown in Fig. 3. It is the lower part of a triangular head made of white flint without a stem, but with a clear notch for mounting into the split shaft. It is $11.6 \mathrm{~mm}$ long and weighs $0.36 \mathrm{~g}$, so we may extrapolate its full length to about $25 \mathrm{~mm}$ and weight to about $0.6 \mathrm{~g}$.

\section{Making an arrow}

The reed arrow was manufactured from material collected in Slovenia, so in certain aspects it departs from historical examples. We also used modern thread and modern synthetic rubber or cellulose acetate glue for fixing; however, we do not believe these additions greatly affect its ballistic properties. The wooden parts were made from straight shoots of dogwood, which has compact wood. For the point, a triangular flake of flint weighing $0.4 \mathrm{~g}$ was inserted into the split in the fore shaft, fixed with cotton thread and glued with synthetic rubber. The wood was split by a saw so as to prevent the shaft from cracking below the point. The shaft was made from a dry reed. After removing the dry leaves, we noticed the importance of properly smoothing the leaf nodes on the stem. We suppose historical arrowsmoothers were mainly used for this type of work. We made a proper notch and fixed three feathers at the end of the shaft, firstly with thread around the front and end parts; finally, we also applied a small amount of glue below the feather's pulp. The feathers were taken from small birds the size of a pigeon or magpie, which are softer than turkey feathers. Fixing the feathers was the most delicate and time-consuming part of the work (see also Odar 2011.453). The end parts of the reed stem were reinforced with cotton fibre and glue. For the final assembly of the three main parts, the sockets were gently wetted with cellulose acetate glue. The linear dimensions and weights of particular parts are shown in Table 1; details can be seen in Fig.4. Our final result was an arrow $70.7 \mathrm{~cm}$ long, but with a remarkably low weight of $9.7 \mathrm{~g}$.

\section{The bow}

We made the bow by following the Apache tradition approximately, as we wanted to produce only a wooden bow with similar properties to suit our ballistic experiments. Most of the mulberry trees in Slo-

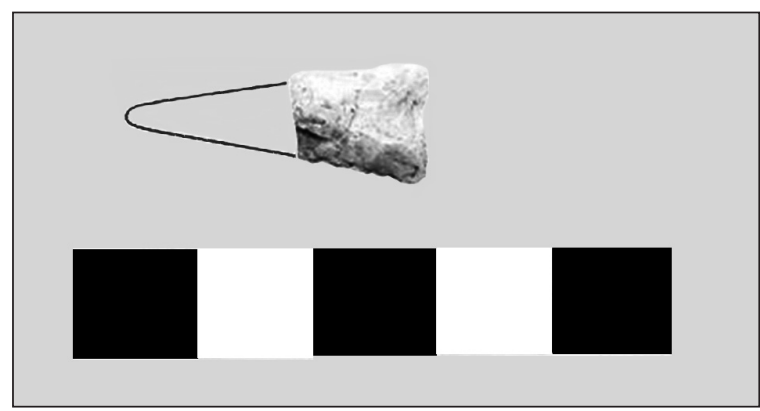

Fig. 3. Fragment of a flint arrow head (Turkey Creek) with supposed reconstruction.

venia are old trees with massive trunks and young branches too thin for bow making. We were able to cut a branch from a yew with the appropriate length and thickness for shaping into a bow. One part was rasped in a limb, applying distinctive tapering, while the other part had to be tapered on the inner side only. The shaped bow was dried for three years before being used. A disadvantage of using such a branch was found to be in the curvature of the bow: it remained significantly curved even when unstrung.

The string was made of hemp cord $1 \mathrm{~mm}$ thick, which was doubled by twisting and then treated with bee wax. When strung, the bow was $105.5 \mathrm{~cm}$ long (Fig. 5). The weight of a full pull for a $70 \mathrm{~cm}$ arrowhead was about $18 \mathrm{~kg}$, but we usually pulled the bow at a weight of $16 \mathrm{~kg}$. We also measured the pull force as a function of the arrow draw distance and estimated that one third of the bow's potential energy is released as kinetic energy in the arrow.

\section{Shooting experiments}

As a first attempt, we tried to determine arrow velocity with an apparatus used to measure the velocity of bullets, but the arrow's velocity was evidently too low to be detected, or the length of the arrow did not produce a short cut-off signal. Therefore, we tried to deduce the take-off velocity from the arrow range when the bow was fired at different angles, simultaneously measuring the flight time. The parameters of the ballistic trajectory can then be determined by means of a model calculation, assuming that

\begin{tabular}{|lcc|}
\hline & $\begin{array}{c}\text { Length/with socket } \\
\text { (cm) }\end{array}$ & $\begin{array}{c}\text { Mass } \\
\text { (g) }\end{array}$ \\
\hline Front shaft with flint tip & $11.7 / 17.6$ & 3.54 \\
\hline Reed middle shaft & 46.3 & 3.51 \\
\hline Feathered end shaft & $12.7 / 15.5$ & 2.65 \\
\hline Total & 70.7 & 9.70 \\
\hline
\end{tabular}

Tab. 1. Dimensions and weights of reed arrow parts. 
the air drag force varies with the square of the projectile's velocity (Laharnar 2011.77$80)$.

Flight time was measured with a stop watch held by the archer in the left hand together with the bow and started at the same time as the arrow was released. The watch was stopped as soon as the archer saw the arrow touch
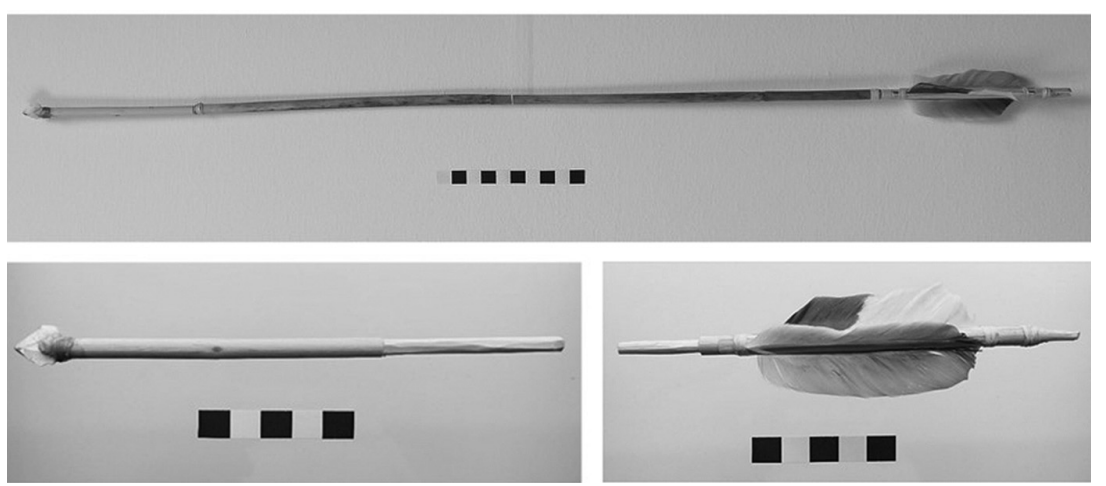

Fig. 4. The reed arrow used for the ballistic experiments.

the ground. Manipulating the stop watch prevented the archer from achieving maximum draw, so we may estimate that the draw weight of the bow was approx. 16kg. The angle of the arrow with respect to ground was also observed and compared with the calculated angle. Range was measured with a steel measuring tape with accuracy better than $0.2 \mathrm{~m}$. The experiments were performed at $300 \mathrm{~m}$ above sea level at temperatures around $20^{\circ} \mathrm{C}$. The reduced air pressure on the day of the experiment was $1015 \mathrm{mbar}$. Subjectively, the feeling of shooting the reed arrow was good. It was possible to perceive that the arrow left the bow at a significant speed, but drag slowed it down noticeably after about $20 \mathrm{~m}$. The flight was stable and did not wobble, in spite of the shaft not being completely straight.

The results of the experiment are presented in the first three columns of Table 2 .

By trial and error, we then looked for the ballistic parameters that matched our measured ranges and
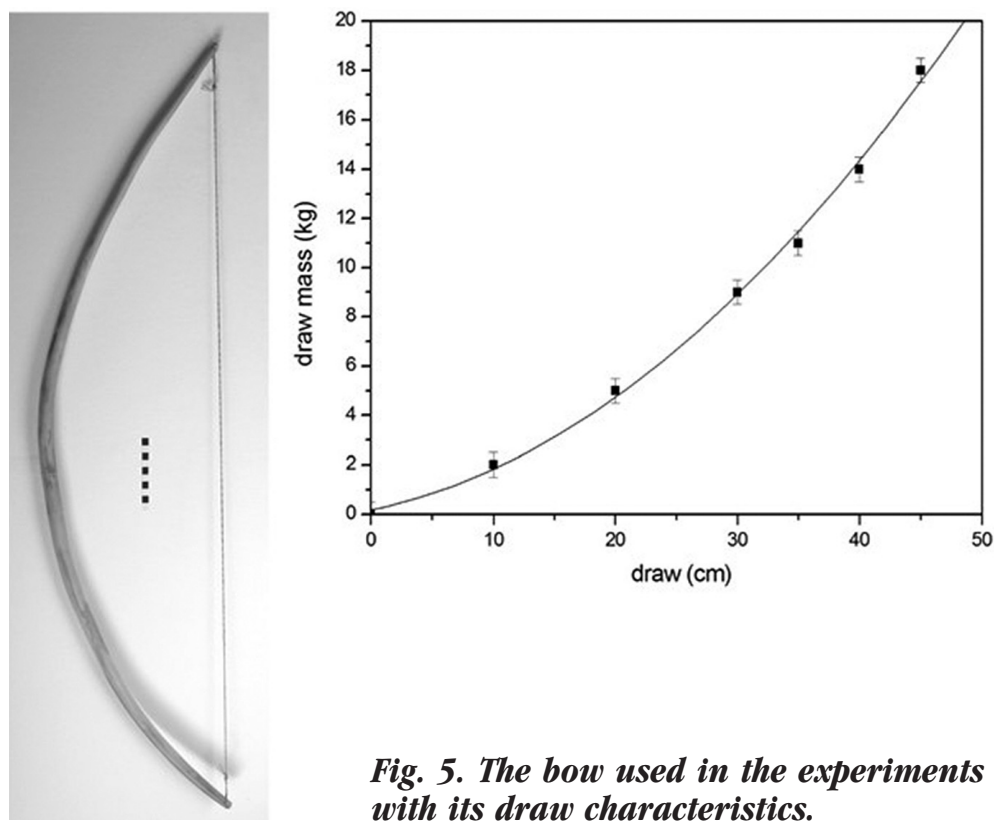

Fig. 5. The bow used in the experiments with its draw characteristics. flight times. The variable parameters were take-off velocity, take-off angle and effective arrow cross section (the physical cross section multiplied by the drag coefficient). Three independent parameters are too many to determine a unique ballistic trajectory, so another principle was selected to discover the effective arrow cross section, which should be the same for all trajectories. As a starting guess, we used data from Jürgen Junkmanns $(2001.57,58)$. A yew bow with $28 \mathrm{~kg}$ pull yielded a take-off velocity of about $50 \mathrm{~m} / \mathrm{s}$ for a flint-tipped arrow with a weight of $30 \mathrm{~g}$, which resulted in a range of $120 \mathrm{~m}$. The simulation gave the effective cross section as $3.5 \mathrm{~cm}^{2}$. We then calculated five sets of take-off velocities for an effective cross section varying between 3.25 and $4.25 \mathrm{~cm}^{2}$ and determined their mean and standard deviations. The realistic cross section corresponded to the values where the spread of take-off velocities was minimal. This principle is based on the supposition that all arrows were shot at approximately the same velocities at different angles. The first two shots in Table 2 were omitted from the calculation, as the archer was still learning to use the bow whilst holding the stopwatch. By plotting the chi-squared rather than standard deviation for the calculated take-off velocities (Fig. 6 ), we found the effective cross section of our arrow was $3.61 \pm 0.5 \mathrm{~cm}^{2}$. This value was then used to determine the ballistic parameters in the second three columns of Table 2.

\section{Discussion of shooting experi- ments}

The ranges in Table 2 appear rather low, but one should remember that they were produced for an extremely light arrow. The ranges and times of flight imply take-off velocities of about $40 \mathrm{~m} / \mathrm{s}$, which is also not high. 


\begin{tabular}{|lccccc|}
\hline $\begin{array}{l}\text { range } \\
(\mathbf{m})\end{array}$ & $\begin{array}{c}\text { time } \\
(\mathbf{s})\end{array}$ & $\begin{array}{c}\text { estim. angle to } \\
\text { ground (deg.) }\end{array}$ & $\begin{array}{c}\text { calculated take-off } \\
\text { velocity }(\mathbf{m} / \mathbf{s})\end{array}$ & $\begin{array}{c}\text { calc. take-off } \\
\text { angle (deg.) }\end{array}$ & $\begin{array}{c}\text { calc. angle to } \\
\text { ground (deg.) }\end{array}$ \\
\hline 44.5 & 2.8 & - & 33.5 & 32 & 50.6 \\
\hline 48.5 & 3.4 & 60 & 36.1 & 39 & 59.9 \\
\hline 47.5 & 4.0 & 60 & 37.6 & 49 & 69.1 \\
\hline 35.5 & 4.9 & 75 & 39.2 & 66 & 79.2 \\
\hline 49.5 & 3.8 & 60 & 38.0 & 45 & 66.2 \\
\hline 51.5 & 3.5 & 60 & 38.7 & 39 & 61.2 \\
\hline
\end{tabular}

Tab. 2. Results of shooting experiments (first three columns from left) and deduced take-off velocity, take-off angle and angle at which the arrow hit the ground for an effective arrow cross section of $3.61 \mathrm{~cm}^{2}$. Air density was taken as $1.16 \mathrm{mg} / \mathrm{cm}^{3}$.

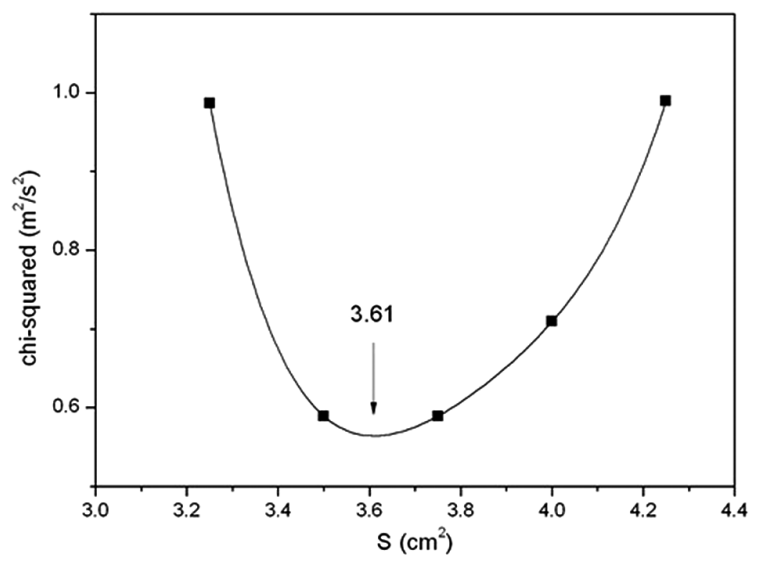

Fig. 6. Determination of effective arrow cross section as a value where the calculated take-off velocities have minimal spread. The fitted curve is fourth order polynomial.

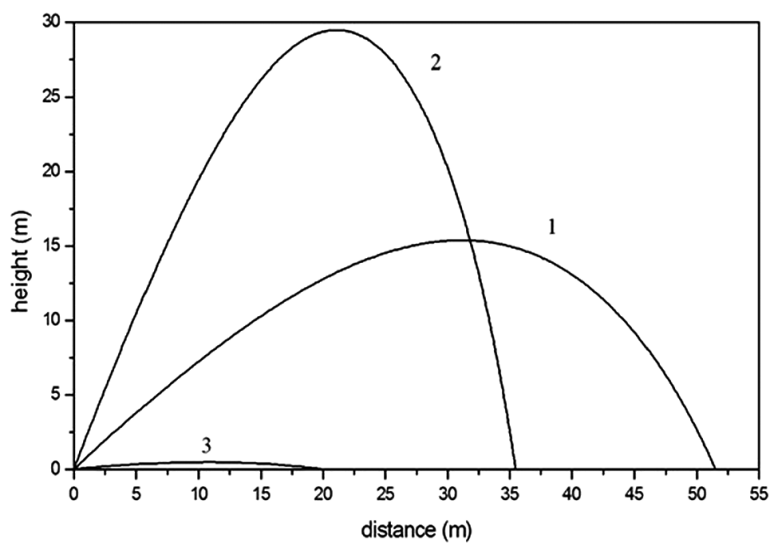

Fig. 7. Numerical simulation of the ballistic trajectories for the longest (1) and highest shot (2) in the experiment and almost flat trajectory for closerange shooting to a distance of $20 \mathrm{~m}$ (3).
However, even if the takeoff velocities were $60 \mathrm{~m} / \mathrm{s}$ and arrows were fired at $2000 \mathrm{~m}$ a. s. 1 ., the maximum range would not exceed $83 \mathrm{~m}$. For a take-off velocity of $45 \mathrm{~m} / \mathrm{s}$, the arrow's kinetic energy is 10J, which is one fifth of the energy of 22LR bullets, and only ten times more than the energy of an air-soft pellet. At a distance of $10 \mathrm{~m}$, this energy is reduced to about $6.2 \mathrm{~J}$, and at a distance of $15 \mathrm{~m}$ it drops to $5 \mathrm{~J}$, half of its initial value.

For comparison, a $30 \mathrm{~g}$ arrow with a take-off velocity of $50 \mathrm{~m} / \mathrm{s}$ (having thus initial kinetic energy of $37.5 \mathrm{~J}$ ) would strike a target $100 \mathrm{~m}$ away with an energy of $11 \mathrm{~J}$. We can conclude that the effective range of reed arrows was well below $20 \mathrm{~m}$. The main advantages of such arrows were that they could reach a reasonable velocity from a bow that was not very strong (as in our experimental case). Using a light bow further enabled the archer to fire more arrows in a short time, which might be essential in a dense fighting melee, and eased aiming, as the trajectory of the light arrow for the first $20 \mathrm{~m}$ is almost straight (Fig. 7).

\section{Conclusion}

The use of reed arrows by the Apaches provided an efficient weapon for close-range hunting and combat. This selection of reed as arrow material is not unique and may not have developed strictly for functional reasons, but because material which is found in the woodland and deserts of the American southwest is less generous with long straight sprouts than bushes in Europe. Nevertheless, historical Apaches used the bow as their principal long-range weapon until the middle of the 19th century and developed a mastery that can serve as an example for current prehistoric models. As the use of light arrows in combat favoured close-range shooting, the rock painting in Cueva del Roure showing Neolithic archers in a short-range fight may indeed represent a realistic case. 


\section{References}

Ball E., Kaywaykla J. 2003. In the Days of Victorio: Recollections of a Warm Springs Apache (1 ${ }^{\text {st }}$ edition in 1970). The University of Arizona Press. Tucson.

Ball E., Henn N. and Sánchez L. A. 1988. Indeh: An Apache Odyssey. University of Oklahoma Press. Norman, London.

Barrett S. M. 1996. Geronimo, His Own Story. As Told to S. M. Barrett. A Meridian Book. Penguin Books. New York.

Basso K. H. (ed.) 1971. Western Apache Raiding and Warfare. From the notes of Grenville Goodwin. The University of Arizona Press. Tucson.

Betsinez J., Nye W. S. 1959. I Fought with Geronimo. University of Nebraska Press. Lincoln, London.

Bonsall C. 2008. The Mesolithic of the Iron Gates. In G. Bailey, P. Spikins (eds.), Mesolithic Europe. Cambridge University Press. Cambridge: 238-452.

Bourke J. G. 1958. An Apache Campaign in the Sierra Madre. An account of the expedition in pursuit of the hostile Chiricahua Apaches in the spring of 1883 (1 1 st edition in 1886). Charles Scribner's Sons. New York 1958.

Chatters J. C. 2014. Wild-type colonizers and high levels of violence among Paleoamericans. In M. W. Allen, T. L. Jones (eds.), Violence and warfare among hunter-gatherers. Left coast press. Walnut Creek: 70- 96.

Christensen J. 2004. Warfare in the European Neolithic. Acta Archaeologica 75: 129-156.

Davis B. 1976. The Truth about Geronimo (Fascimile of 1929 Edition). University of Nebraska Press. Lincoln, London.

Erdal Y. S., Dilek Erdal Ö. D. 2012. Organized violence in Anatolia: A retrospective research on the injuries from the Neolithic to Early Bronze Age. International Journal of Paleopathology 2: 78-92.

Hutton Estabrook V. 2014. Violence and warfare in the European Mesolithic and Paleolithic. In M. W. Allen, T. L. Jones (eds.), Violence and warfare among hunter-gatherers. Left coast press. Walnut Creek: 49-69.

Junkmanns J. 2001. Pfeil und Bogen. Herstellung und Gebrauch in der Jungsteinzeit. Museum Schwab. Biel.

Kramer C. 1979. Introduction. In C. Kramer (ed.), Ethnoarchaeology. Implications of Ethnography for Archaeo$\log y$. Columbia University Press. New York: 1-20.

Laharnar B., Šmit Ž. and Ravbar I. 2011. Sling and slingshots - An example of experimental archaeology and ap- plication of statistical methods in archaeology. Arheo 28 : 73-86.

LeBlanc S. A. 2014. Forager warfare and our evolutionary past. In M. W. Allen, T. L. Jones (eds.), Violence and warfare among hunter-gatherers. Left coast press. Walnut Creek: 26-46.

Lehmann H. 1993. Nine Years among the Indians (1st edition in 1927). University of New Mexico Press. Albuquerque.

Odar B. 2011. Archers at Potočka zijalka. Arheološki vestnik 62: 433-456.

Opler M. E. 1994. Myths and Tales of the Chiricahua

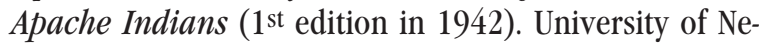
braska Press. Lincoln, London.

1996. An Apache life-way. The economic, social, and religious institutions of the Chiricahua Indians. University of Chicago Press. Chicago.

Robinson S. 2000. Apache Voices. Their Stories as Told to Eve Ball. University of New Mexico Press. Albuquerque.

Roksandić M. 2006a. Violence in the Mesolithic. Documenta Praehistorica 33: 165-182.

2006b. Interpersonal violence at Lepenski Vir, Mesolithic/Neolithic Complex of the Iron Gates gorge (SerbiaRomania). American Journal of Physical Anthropology 129: 339-348.

Sides H. 2007. Blood and Thunder, The epic story of Kit Carson and the conquest of the American West. Anchor Books. New York.

Sonnichsen C. L. 1958. The Mescalero Apaches. University of Oklahoma Press. Norman.

Sweeney E. R. 1991. Cochise, Chiricahua Apache Chief. University of Oklahoma Press. Norman.

2010. From Cochise to Geronimo: The Chiricahua Apaches, 1874-1886. University of Oklahoma Press. Norman.

Thrapp D. L. 1974. Victorio and the Mimbres Apaches. University of Oklahoma Press. Norman.

Utley R. M. 1977. A Clash of Cultures, Fort Bowie and the Chiricahua Apaches. National Park Service. Washington.

2012. Geronimo. Yale University Press. New Haven, London. 
